\title{
Phytotoxic metabolites from Neofusicoccum parvum, a pathogen of Botryosphaeria dieback of grapevine
}

\author{
Eliane Abou-Mansour ${ }^{\mathrm{a}, *}$, Jean-Luc Débieux $^{\mathrm{a}}$, Montserrat Ramírez-Suero ${ }^{\mathrm{b}}$, Mélanie Bénard-Gellon ${ }^{\mathrm{b}}$, \\ Maryline Magnin-Robert ${ }^{\mathrm{c}}$, Alessandro Spagnolo ${ }^{\mathrm{a}, \mathrm{c}}$, Julie Chong ${ }^{\mathrm{b}}$, Sibylle Farine ${ }^{\mathrm{b}}$, Christohpe Bertsch ${ }^{\mathrm{b}}$, \\ Floriane L'Haridon ${ }^{a}$, Mario Serrano ${ }^{a}$, Florence Fontaine ${ }^{c}$, Cecilia Rego ${ }^{d}$, Philippe Larignon ${ }^{\mathrm{e}}$ \\ ${ }^{a}$ Department of Biology, University of Fribourg, Ch. du Musée 10, 1700 Fribourg, Switzerland \\ ${ }^{\mathrm{b}}$ Laboratoire Vigne Biotechnologie et Environnement EA 3991, Université de Haute-Alsace, 33, rue de Herrlisheim, BP 68008 Colmar Cedex, France \\ 'Laboratoire Stress Défense et Reproduction des Plantes EA 4707, Université de Reims Champagne-Ardenne, UFR Sciences, Moulin de la Housse, 51687 Reims Cedex 2, France \\ ${ }^{\mathrm{d}}$ Institut Supérieur d'Agronomie, Tapada da Ajuda, Lisbonne, Portugal \\ e Institut Français de la Vigne et du Vin Pôle Rhône-Méditerranée, France, Domaine de Donadille, 30230 Rodilhan, France
}

\section{A R T I C L E I N F O}

Article history:

Received 12 September 2014

Received in revised form 18 January 2015

Available online 5 March 2015

\section{Keywords:}

Neofusicoccum parvum

Botryosphaeria dieback

Esca

Phytotoxins

Dihydrotoluquinones

Isocoumarins

Epoxylactones

Vitis vinifera cells (calli)

Defence gene expression

\begin{abstract}
A B S T R A C T
Liquid chromatography-diode array screening of the organic extract of the cultures of 13 isolates of the fungus Neofusicoccum parvum, the main causal agent of botryosphaeria dieback of grapevine, showed similar metabolites. One strain was selected for further chemical studies and led to the isolation and characterisation of 13 metabolites. Structures were elucidated through spectroscopic analyses, including one- and two-dimensional NMR and mass spectrometry, and through comparison to literature data. The isolated compounds belong to four different chemical families: five metabolites, namely, $(-)$-terremutin (1), (+)-terremutin hydrate (2), (+)-epi-sphaeropsidone (3) (-)-4-chloro-terremutin hydrate (4) and(+)-4hydroxysuccinate-terremutin hydrate (5), belong to the family of dihydrotoluquinones; two metabolites, namely, $(6 S, 7 R)$ asperlin $(\mathbf{6})$ and $(6 R, 7 S)$-dia-asperlin (7), belong to the family of epoxylactones; four metabolites, namely, $(R)-(-)$-mellein $(\mathbf{8}),(3 R, 4 R)$-4-hydroxymellein $(\mathbf{9}),(3 R, 4 S)$-4-hydroxymellein (10) $(R)(-)$-3-hydroxymellein (11), belong to the family of dihydroisocoumarins; and two of the metabolites, namely, 6-methyl-salicylic acid (12) and 2-hydroxypropyl salicylic acid (13), belong to the family of hydroxybenzoic acids. We determined the phytotoxic activity of the isolated metabolites through a leaf disc assay and the expression of defence-related genes in Vitis vinifera cells cv. Chardonnay cultured with (-)-terremutin (1), the most abundant metabolite. Finally, analysis of the brown stripes of grapevine wood from plants showing botryosphaeria dieback symptoms revealed the presence of two of the isolated phytotoxins.
\end{abstract}

(c) 2015 Elsevier Ltd. All rights reserved.

\section{Introduction}

Grapevine trunk diseases cause decline and premature dieback of vineyards and have become a growing threat to grapevine production worldwide. Losses up to $50 \%$ of the normal yield have been reported (Bertsch et al., 2013; Hofstetter et al., 2012; Luque et al., 2009; Úrbez-Torres et al., 2006; Mugnai et al., 1999). Esca and botryosphaeria dieback are complex diseases in which both the symptoms and the time course of their expression are highly variable. Many fungi have been reported to be involved in these diseases, mainly Phaeomoniella chlamydospora, Phaeoacremonium aleophilum, Fomitiporia mediterranea, Eutypa lata, and

\footnotetext{
* Corresponding author. Tel.: +4126300 8805 .

E-mail address: eliane.abou-mansour@unifr.ch (E. Abou-Mansour).
}

Botryosphaeria spp. (Bertsch et al., 2013). For many years, Botryosphaeriaceous species have been mostly considered saprophytes or secondary colonisers in grapevine (Phillips, 2002). Thus, their pathogenicity has been underestimated, and their epidemiology remains not fully investigated. To date, 30 botryosphaeriaceous species, including Neofusicoccum parvum, have been reported to be involved in dieback disease (Spagnolo et al., 2014a; Luque et al., 2009; Taylor et al., 2005; Úrbez-Torres, 2011). The wood symptoms of botryosphaeria dieback are associated with brown stripes located in the outer xylem. The discoloration appears as an orange/brown colour in the longitudinal direction just beneath the bark and may extend from the trunk to the rootstock and annual stems. The brown stripes are always associated with foliar symptoms (Larignon et al., 2001). Because the pathogens cannot be detected in the leaves of infected plants (Larignon and Dubos, 
1997; Mugnai et al., 1999), it was hypothesised that foliar symptoms are caused by phytotoxic compounds produced by the fungi in wood tissue, which are either translocated to the leaves or induce a chain reaction leading to the expression of the symptoms in the leaves. Several secondary metabolites have been found in Botryosphaeriaceae spp., but only three lipophilic compounds has been identified from $N$. parvum (Evidente et al., 2010), the predominant species recovered from grapevines displaying symptoms of dieback and decline. The present study aimed (i) to further characterise the phytotoxins of $N$. parvum, (ii) to evaluate their phytotoxicity, (iii) to investigate the expression of plant defencerelated genes in response to (-)-terremutin (1), the most abundant phytotoxic compound identified from the culture, and finally, (iv) to determine the presence of the phytotoxins in grapevine wood showing botryosphaeria dieback symptoms.

\section{Results and discussion}

\subsection{Extraction, purification and identification of phytotoxins}

Thirteen N. parvum fungi isolated from grapevine plants showing decline collected from vineyards or nurseries (Table 1) were each grown on ten potato dextrose plates and extracted with ethyl acetate. The extracts were screened for the production of secondary metabolites by HPLC-DAD analysis and for phytotoxic activity through a leaf disc assay of the host plant Vitis vinifera $\mathrm{cv}$. Chardonnay. The secondary metabolite patterns of all 13 strains were identical to differences in the concentrations of each compound (Supplementary Fig. S1), and all of the analysed strains showed phytotoxic activity at different levels (Supplementary Fig. S2). Strain Bourgogne 2S-16 (Bourg) was selected due to its rapid growth and the presence of diverse metabolites. The ethyl acetate-soluble extract of a scaled-up culture on PDA plates of Bourg was subjected to silica gel column chromatography before separation by semi-preparative reverse-phase HPLC. The purification resulted in the isolation of 13 compounds (1-13). Two of the isolated compounds ( $\mathbf{4}$ and $\mathbf{5}$ ) are described for the first time, eight compounds $(\mathbf{1}, \mathbf{2}, \mathbf{3}, \mathbf{6}, \mathbf{7}, \mathbf{1 1}, 12$ and $\mathbf{1 3})$ are reported for the first time from $N$. parvum, and three compounds $(\mathbf{8}, \mathbf{9}$ and $\mathbf{1 0})$ were

\section{Table 1}

Name of screened isolates and their origin. Isolates from (a) IFV France and (b) University of Lisboa, Portugal.

\begin{tabular}{|c|c|c|}
\hline Isolate name & Isolated from & Symptoms \\
\hline aF003. & Vineyard, cv. Syrah & Decline \\
\hline${ }^{\mathrm{a} B W} 2 \mathrm{BB}$ & Vineyard, cv. Chardonnay & Decline \\
\hline${ }^{\mathrm{a} C h a r e n t e s} 11 \mathrm{G}$ & $\begin{array}{l}\text { Nursery plant, cv. Ugni } \\
\text { blanc }\end{array}$ & \\
\hline aVaucluse 14-PG1 & $\begin{array}{l}\text { Nursery plant, R110 } \\
\text { rootstock }\end{array}$ & \\
\hline aBourgogne 2S-16 & $\begin{array}{l}\text { Nursery plant, cv. } \\
\text { Chardonnay }\end{array}$ & \\
\hline${ }^{\mathrm{a} S a i n t e}$ Victoire & Vineyard cv. Grenache & Decline, BDA \\
\hline${ }^{\mathrm{a} C h a r e n t e s}$ 26S & $\begin{array}{l}\text { Nursery plant, cv. Ugni } \\
\text { blanc }\end{array}$ & \\
\hline${ }^{\mathrm{b}} \mathrm{Bt} 2$ & $\begin{array}{l}\text { Vineyard, cv. Alvarinho, } \\
9 \text { years old }\end{array}$ & Esca; esca-like symptoms \\
\hline${ }^{\mathrm{b}} \mathrm{Bt} 19$ & $\begin{array}{l}\text { Vineyard, cv. Alfrocheiro, } \\
3 \text { years old }\end{array}$ & $\begin{array}{l}\text { Decline, black streaks, } \\
\text { hard necrosis }\end{array}$ \\
\hline${ }^{\mathrm{b}} \mathrm{Bt} 67$ & $\begin{array}{l}\text { Vineyard, cv. Fernão Pires, } \\
25 \text { years old }\end{array}$ & Esca; esca-like symptoms \\
\hline${ }^{\mathrm{b}} \mathrm{Bt} 75$ & $\begin{array}{l}\text { Vineyard, cv. Trincadeira, } \\
7 \text { years old }\end{array}$ & BDA \\
\hline${ }^{\mathrm{b}} \mathrm{Bt} 80$ & $\begin{array}{l}\text { Vineyard, cv. Trincadeira, } \\
3 \text { years old }\end{array}$ & $\begin{array}{l}\text { Decline, black streaks, } \\
\text { hard necrosis }\end{array}$ \\
\hline${ }^{\mathrm{b}} \mathrm{Bt} 85$ & $\begin{array}{l}\text { Vineyard, cv. Syrah, } \\
2 \text { years old }\end{array}$ & BDA \\
\hline
\end{tabular}

reported previously from $N$. parvum (Evidente et al., 2010). The isolated compounds belong to four different chemical families: dihydrotoluquinone, epoxylactone, dihydroisocoumarin and hydroxybenzoic acid (Fig. 1).

The major compound ( $140 \mathrm{mg}$ ) was obtained by precipitation from methanol with chloroform, and the molecular formula of $\mathrm{C}_{7} \mathrm{H}_{8} \mathrm{O}_{4}$ was deduced from the ${ }^{1} \mathrm{H},{ }^{13} \mathrm{C}$ NMR and ESIMS(-) spectra $m / z 155[\mathrm{M}-\mathrm{H}]^{-}$, indicating four degrees of unsaturation. The UV spectrum showed an absorption $\lambda_{\max } 273 \mathrm{~nm}$, indicating the presence of a conjugated enone chromophore. The ${ }^{13} \mathrm{C}$ NMR spectrum showed an $\alpha, \beta$-unsaturated ketone $\left(\delta_{\mathrm{C}} 193.4,171.5\right.$, and 109.52) with the quaternary carbon $\left(\delta_{\mathrm{C}} 171.5\right)$ bearing oxygen, one methyl $\left(\delta_{\mathrm{C}} 7.4\right)$ and three oxygenated methines ( $\delta_{\mathrm{C}} 66.4,55.6$, and 52.6 ). These results, as well as the ${ }^{1} \mathrm{H}$ NMR and 2D NMR, HMQC, HMBC and $C D$ spectra, are in accordance with the structure of (-)-terremutin (1) obtained from a mutant strain of Aspergillus terreus (Miller, 1968).

The ESIMS(+) spectra of compound (2), $m / z 175.1[\mathrm{M}+\mathrm{H}]^{+}$for $\mathrm{C}_{7} \mathrm{H}_{10} \mathrm{O}_{5}$, indicated the presence of an additional hydroxyl group. The coupling constant $J_{5,6}(9.5 \mathrm{~Hz})$ is in accordance with a trans disposition of $\mathrm{H}_{5}$ and $\mathrm{H}_{6}$ together with an upfield shift of the carbon atoms of the methines from $\delta_{c} 55.6$ and 52.6 to $\delta_{c} 76.5$ and 73.4, indicating the opening of the oxirane ring. The UV, ${ }^{1} \mathrm{H}$ and ${ }^{13} \mathrm{C}$ NMR and $[\alpha]_{D}$ spectral data confirmed the structure as (+)-terremutin hydrate (Kiriyama et al., 1977; Tsuda et al., 1980).

Compound (3) showed the same $m / z 155[\mathrm{M}-\mathrm{H}]^{-}$as (1). The UV, ${ }^{1} \mathrm{H}$ and ${ }^{13} \mathrm{C}$ NMR spectral data indicated the loss of the methyl group in position $\mathrm{C}-2$ and the replacement of the hydroxyl in position C-3 by a methoxyl group. The NMR data are in accordance with the data reported for epi-sphaeropsidone (Evidente et al., 1998). The CD spectra showed a positive Cotton effect at $311 \mathrm{~nm}$ ( $R$ band $270+23.9 ; \mathrm{K}$ band $260 \mathrm{~nm}-3.41$ ) and a positive $[\alpha]_{D}$ +210 ( c 0.03), as previously observed in other structurally related compounds, such as (+)-epi-epoxydon (Fex and Wickberg, 1981; Nagasawa et al., 1978). These results are opposite to the data reported for (-)-terremutin and (-)-epi-sphaeropsidone from Sphaeropsis sapinea (Evidente et al., 1998; Mennucci et al., 2007), indicating that the isolated compound was (+)-epi-sphaeropsidone (3) (Supplementary Fig. S3).

The mass spectra of compound (4) showed the specific pattern of a chlorine substitution. HR-ESIMS(+) $\mathrm{m} / \mathrm{z} 215.0082[\mathrm{M}+\mathrm{Na}]^{+}$for $\mathrm{C}_{7} \mathrm{H}_{9} \mathrm{ClO}_{4}$ (calculated 215.0087). The comparison of the ${ }^{1} \mathrm{H}$ and ${ }^{13} \mathrm{C}$ NMR spectral data with the data obtained for compound (2) showed an upfield shift for carbon atom C-4 ( $\left.\delta_{c} 64.7\right)$. The observation of an HMBC correlation from $\mathrm{H}-4 \delta_{H} 4.41(\mathrm{~d}, J=9.3 \mathrm{~Hz}, 1 \mathrm{H})$ to C-4 correlates with the structure of compound (4) as 4-chloro3,5,6-trihydroxy-2-methylcyclohex-2-enone or 4-chloro-terremutin hydrate, indicating that it was isolated for the first time in this study.

The ESI-MS(-) of compound (5) showed the molecular ion $\mathrm{m} / \mathrm{z}$ $273.0[\mathrm{M}-\mathrm{H}]^{-}$for $\mathrm{C}_{11} \mathrm{H}_{14} \mathrm{O}_{8}$ and $\mathrm{MS}^{2}$ fragments $\mathrm{m} / \mathrm{z} 213,173$ and 155 for the loss of $\mathrm{CH}_{2} \mathrm{COOH}, \mathrm{CO}\left(\mathrm{CH}_{2}\right)_{2} \mathrm{COOH}$ and $\left(\mathrm{CH}_{2}\right)_{2}(\mathrm{COOH})_{2}$, respectively. The ${ }^{1} \mathrm{H},{ }^{13} \mathrm{C}$ NMR and $\mathrm{CD}$ and $[\alpha]_{\mathrm{D}}$ data showed similarities to those of compound (2). An AB system in ${ }^{1} \mathrm{H}$ NMR data together with the ${ }^{13} \mathrm{CNMR}$ data and $\mathrm{MS}^{n}$ fragmentation pattern indicate the presence of an additional succinic acid $\mathrm{C}_{4} \mathrm{O}_{3} \mathrm{H}_{5}$ moiety. The correlation in HMBC from $\mathrm{H}-4\left(\delta_{H} 5.47\right)$ to $\mathrm{C}-1^{\prime}\left(\delta_{C} 174.6\right)$ of succinic acid carbonyl correlates with a C-4. Compound (5) was identified as (+)-3-(2,5,6-trihydroxy-3-methyl-4-oxocyclohex-2enyloxycarbonyl)-propanoic acid or 4-hydroxysuccinate-terremutin hydrate (5), which was isolated for the first time in this study.

Compounds (6) and (7) showed the same UV spectra with $\lambda_{\max }$ $229 \mathrm{~nm}$ and mass spectra $\mathrm{m} / z 235.3[\mathrm{M}+\mathrm{Na}]^{+}$, indicating a molecular formula of $\mathrm{C}_{10} \mathrm{H}_{12} \mathrm{O}_{5} \mathrm{Na}$. Based on the detailed ${ }^{1} \mathrm{H},{ }^{13} \mathrm{C}$ NMR and 2D NMR, COSY and HMBC spectra, compound (6) was identified as 


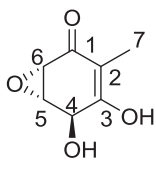

1<smiles>CC1=C(O)[C@H](O)[C@H](O)[C@H](O)C1=O</smiles>

2<smiles>COC1=CC(=O)[C@@H]2O[C@H]1[C@H]2O</smiles>

3<smiles>CC1=C(O)C(Cl)C(O)C(O)C1=O</smiles><smiles>CC1=C(O)C(OC(=O)O)C(O)C(O)C1=O</smiles><smiles>CC(=O)O[C@H]1C=CC(=O)O[C@@H]1C1OC1C</smiles><smiles>COC[C@H]1OC(=O)C=C[C@@H]1OC(C)=O</smiles><smiles>C[C@@H]1OC(=O)c2c(O)cccc21</smiles>

8

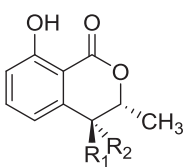

$9 \mathrm{R} 1=\mathrm{OH} \quad \mathrm{R} 2=\mathrm{H}$

$10 \mathrm{R} 1=\mathrm{H}$<smiles>O=C1OC(O)Cc2cccc(O)c21</smiles>

11

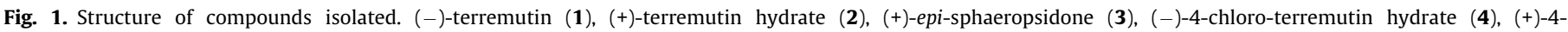

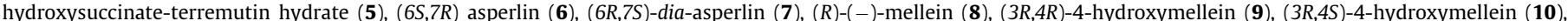
$(R)(-)-3$-hydroxymellein (11), 6-methyl-salicylic acid (12) and 2-hydroxypropyl salicylic acid (13).

(+)-asperlin, which was previously reported from cultures of Aspergillus nidulans (Argoudelis and Zieserl, 1966; Yang et al., 1997; Komai et al., 2003), and compound (7) as (+)-(6R, 7S)-dia-asperlin, which was originally reported from Aspergillus caespitosus (Mizuba et al., 1975; Yang et al., 1997). This structure was confirmed by a synthetic method (Murayama et al., 1987).

Compounds (8) to (11) were identified as dihydroisocoumarins, as determined from their specific UV spectra with $\lambda_{\max } 246$ and $315 \mathrm{~nm}$. Compounds (8) to (10), namely $(R)-(-)$-mellein, $(3 R, 4 R)-$ 4-hydroxymellein and $(3 R, 4 S)$-4-hydroxymellein, presented $[\alpha]_{D}^{25}$, $\mathrm{CD}, \mathrm{UV},{ }^{1} \mathrm{H}$ and ${ }^{13} \mathrm{C}$ NMR and ESIMS spectra that were identical to those previously reported (Djoukeng et al., 2009; Cole and Cox, 1981; Asha et al., 2004). The molecular formula of compound (11) was determined as $\mathrm{C}_{10} \mathrm{H}_{10} \mathrm{O}_{4}$ from ESIMS $(-) \mathrm{m} / z 193[\mathrm{M}-\mathrm{H}]^{-}$. The AB coupling system of $\mathrm{H}-4\left[\delta_{\mathrm{H}} 3.26(\mathrm{~d}, J=16.3 \mathrm{~Hz}), 3.16\right.$ (d, $J=16.3 \mathrm{~Hz})]$ and the upfield shift of the methyl group $\left(\delta_{C} 28.5\right)$ were in favour of the hydroxyl substitution C-3. The compound was identified as 3-hydroxymellein, which was isolated from Aspergillus oniki 1784 (Sasaki et al., 1970). This report provides the first ${ }^{1} \mathrm{H}$ and ${ }^{13} \mathrm{C}$ NMR data. The CD spectrum of compound (11) overlapped with that of $(-)-(R)$-mellein (negative extrema at 270 and $220 \mathrm{~nm}$ ), confirming its structure as $(-)-(R)$-3-hydroxymellein, which was isolated from Botryosphaeria sp. for the first time.

The molecular formula of compound (12) was deduced to be $\mathrm{C}_{8} \mathrm{H}_{8} \mathrm{O}_{3}$ from ESI-MS(-) $m / z 151[\mathrm{M}-\mathrm{H}]^{-}$with the parent ion $m /$ $z$ 107, indicating the loss of $\mathrm{CO}_{2}$. The UV $(\mathrm{MeOH}) \lambda_{\max } 243$ and $307 \mathrm{~nm}$ and ${ }^{1} \mathrm{H}$ and ${ }^{13} \mathrm{C}$ NMR data allowed the identification of 6methyl salicylic acid from Peltaster fructicola, which showed low antifungal activity against Diplodia seriata (Botryosphaeria obtusa) (Venkatasubbaiah et al., 1995; Zhang et al., 2013), and from A. terreus (Fujii et al., 1996). 6-Methyl salicylic acid has been reported to mimic salicylic acid in tobacco by enhancing the accumulation of pathogenesis-related (PR) proteins PR1 and $\beta$-1,3-glucanase (Nasser et al., 2001).

Finally, compound (13) showed UV (MeOH) $\lambda_{\max } 243$ and $304 \mathrm{~nm}$, ES-IMS $(-) m / z 195[\mathrm{M}-\mathrm{H}]^{-}$for $\mathrm{C}_{10} \mathrm{H}_{12} \mathrm{O}_{4}$ with $\mathrm{MS}^{2}$ fragment ions $\mathrm{m} / \mathrm{z} 177$ corresponding to $\left[\mathrm{M}-\mathrm{H}-\mathrm{H}_{2} \mathrm{O}\right]^{-}$and $\mathrm{m} / \mathrm{z} 107$ $\left[(\mathrm{M}-\mathrm{H})-\mathrm{CHCH}_{3} \mathrm{OCO}_{2}\right]^{-}$. The structure of compound (13) was confirmed to be 6-(2-hydroxypropyl)-salicylic acid by comparing the ${ }^{1} \mathrm{H}$ and ${ }^{13} \mathrm{C}$ NMR data with published data for flemingipanic acid isolated from the stem bark of Flemingia paniculata (Rahman et al., 2004) and from an Alternaria sp. (HS-3) isolate associated with a sea cucumber (Xia et al., 2011).

\subsection{Phytotoxic activity}

The phytotoxic activity of seven of the major isolated compounds was recorded $48 \mathrm{~h}$ post-inoculation at two concentrations, namely 100 and $200 \mu \mathrm{g} \mathrm{mL}^{-1}$, on leaf discs of $V$. vinifera $\mathrm{cv}$. Chardonnay (Fig. 2). All of the compounds tested induced necrosis on host plant leaves of Chardonnay, Pinot noir, and Chasselas and non-host plant leaves of Arabidopsis thaliana (data not included). Despite the known phytotoxic activity of $(-)$-mellein (8) and $(3 R, 4 S)$ and $(3 R, 4 R)-4$-hydroxymellein $(\mathbf{9}, \mathbf{1 0})$ (Djoukeng et al., 2009, Evidente et al., 2010), these compounds were included in the assay to compare their activities with that of the newly isolated (-)-R-3-hydroxymellein (11). The results showed that (-)-R-3-hydroxymellein (11) was the most active at a low concentration $\left(100 \mu \mathrm{g} \mathrm{mL}^{-1}\right)$, inducing a necrosis area greater than $50 \%$, followed by $(+)$-epi-sphaeropsidone (3) with $25 \%$ leaf disc necrosis. At $200 \mu \mathrm{gL}^{-1}(-)-R$-3-hydroxymellein (11) and (-)-terremutin (1) induced the greatest extent of necrosis, followed by $(-)$-mellein (8), (+)-epi-sphaeropsidone (3) and (6R,7S)-dia-asperlin (7).

Dihydroisocoumarins have been isolated from several fungi, including species from the Aspergillus, Cercospora, Cryptosporiopsis, Hypoxylon, Phoma, and Xylaria genera (the list is not exhaustive) with phytotoxic, zootoxic and moderate antifungal activities (Turner and Aldridge, 1983; Cabras et al., 2006). Compounds 8, 9 and $\mathbf{1 0}$ were isolated from N. parvum (Evidente et al., 2010) with 7-hydroxymellein and 4,7-dihydroxymellein, which are phytotoxins produced by (D. seriata) B. obtusa from grapevine (Djoukeng et al., 2009). Recently, (-)-mellein $\left(500 \mu \mathrm{g} \mathrm{mL}^{-1}\right.$ ) was reported to induce partial necrosis on grapevine cv. Chardonnay calli and to significantly induce the gene encoding PR protein after 6 days of contact (Ramírez-Suero et al., 2014).

In this study, (-)-terremutin (1) was present at a high concentration in all N. parvum isolates. A moderate radical scavenging activity of (1) was reported by Dewi et al. (2012), but the phytotoxic activity of this compound has not yet been examined. In contrast, the structurally related group of epoxydon toxins, 


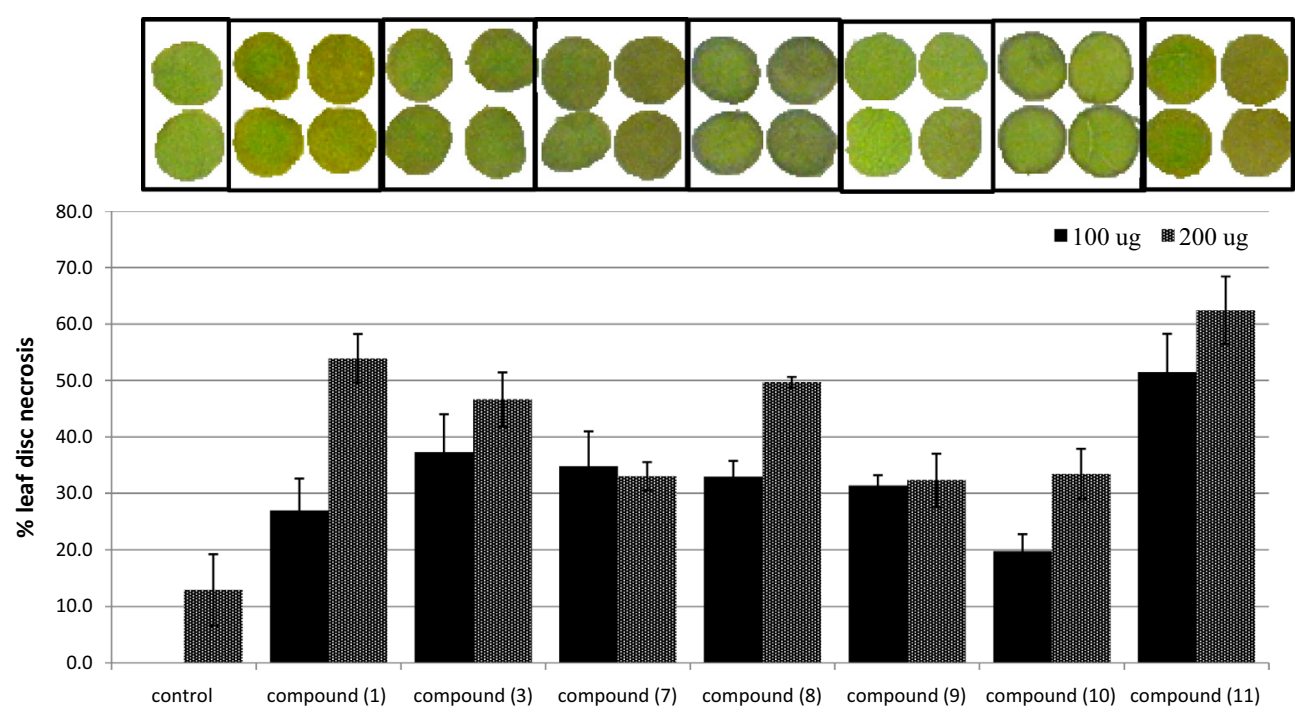

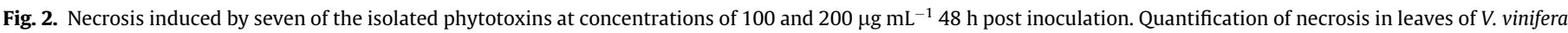

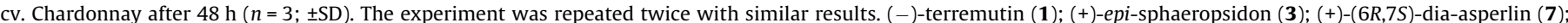

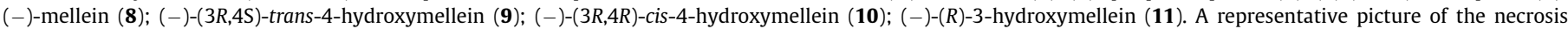
caused by the toxin is placed above each histogram as a visual illustration.

together with 6-methyl salicylic acid, from Stagonospora sacchari and Phoma sp. have been reported to have phytotoxic and antibacterial activity (Venkatasubbaiah et al., 1987; Venkatasubbaiah and Chilton, 1992). Compound (1) was able to induce necrosis in the leaf disc assay (Fig. 2), and through infiltration into full leaves of $V$. vinifera and $A$. thaliana (data not shown). Compound (1) showed mild antibacterial activity against Pseudomonas fluorescens with an MIC of $50 \mu \mathrm{g} \mathrm{mL}^{-1}$ (data not shown).

In an investigation of leaf stripe development in Esca disease, Magnin-Robert et al. (2011) found that defence-related gene expression is affected and detected early in presymptomatic leaves of cv. Chardonnay and amplified during symptom expression. To evaluate the phytotoxic effects of (-)-terremutin (1), we examined the expression pattern of several defence-related genes in grapevine calli cv. Chardonnay as described by Ramírez-Suero et al., 2014: genes participating in cellular detoxification ( $V v G S T 1$ and $V v S O D)$, the jasmonic acid pathway ( $V v A O S$ and $V v L O X)$, synthesis of secondary metabolites of the phenylpropanoid pathway ( $V v P A L)$, phytoalexin production ( VvSTS1), flavonoid synthesis ( $V v F 3 H$ and $V v F M T)$ and pathogenesis-related proteins (PR-P) (VvPR6, VvGLU, $V v C H I T 4 c$ and $V v P R 10.1)$. The assay was performed at two concentrations ( 25 and $200 \mu \mathrm{g} \mathrm{mL}^{-1}$ ), and the results were recorded at 1 , 3 , and 6 days post inoculation. At $25 \mu \mathrm{g} \mathrm{mL}^{-1}$, no necrosis was observed, and none of the tested (PR-P) genes were induced at either 3 or 6 days post inoculation (data not shown). Indeed, at $200 \mu \mathrm{g} \mathrm{mL}^{-1}$ in the presence of (-)-terremutin (1), necrosis was observed in $20 \%$ and $50 \%$ of the calli after three (data not shown) and 6 days of contact (Fig. 3A), indicating that the phytotoxic effect was time-dependant. The expression of defence-related genes was not induced after 3 days of contact. However, after 6 days, the expression of genes involved in the cellular detoxification, jasmonic acid, phenylpropanoid and flavonoid pathways, namely $V v G S T 1$, $V v A O S, V v P A L$ and $V v F 3 H$, respectively, was significantly induced (Fig. $3 \mathrm{~B}$ ), but the genes encoding enzymes involved in phytoalexin biosynthesis, such as VvSTS1, were not induced. GSTs are known to be induced by xenobiotics, such as toxins (Marrs, 1996), and may thus be important in the removal of toxins in grapevine cells by limiting the induction of oxidative stress. However, (-)-terremutin (1) induces cell death after 3 days by a signalling cascade that differs from a defence-related pathway leading to necrosis, but this pathway still needs to be elucidated. These results suggest that

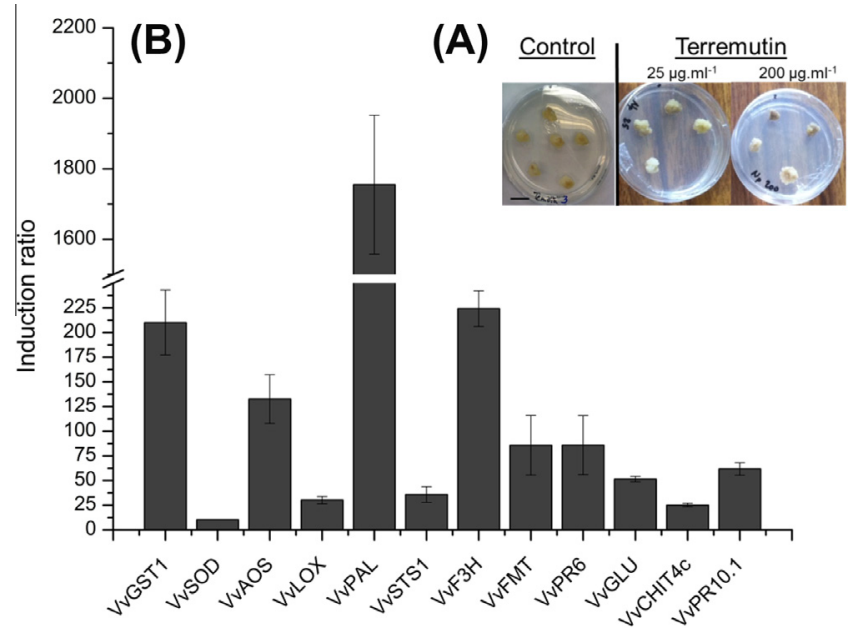

Fig. 3. (A) Calli subcultured in Petri dishes with malt medium: (control) and (-)terremutin (1) (25 and $200 \mu \mathrm{g} \mathrm{mL}^{-1}$ ) 6 days post inoculation. (B) Defence gene expression in calli of $V$. vinifera cv. Chardonnay subcultured in Petri dishes with $200 \mu \mathrm{g} \mathrm{mL}^{-1}$ terremutin (1) at 6 days post inoculation. Gene expression was assessed by RT-qPCR, and the values shown are relative to the non-induced control samples. The genes tested encode cellular detoxification enzymes (VvGST1 and $V v S O D)$, jasmonic acid pathway enzymes ( $V v A O S$ and $V v L O X)$, enzymes for secondary metabolites of the phenylpropanoid pathway ( $V v P A L)$, phytoalexin pathway enzymes ( $V v S T S 1)$, flavonoid pathway enzymes ( $V v F 3 H$ and $V v F M T)$, and pathogenesis-related proteins ( $V v P R 6, V v G L U, V v C H I T 4 c$, and $V v P R 10.1)$. Each data point represents the mean from three technical and two biological replicates. The error bars represent the standard errors of the mean. Significant differential gene expression was defined with an induction ratio higher than 4 .

grapevine calli may perceive some signals and react too late by triggering defence pathways and that cells may thus ultimately become overwhelmed by the phytotoxin.

In comparison, (-)-mellein (8) did not induce necrosis at $200 \mu \mathrm{g} \mathrm{mL}^{-1}$, and only led to the expression of genes involved in cellular detoxification and those encoding pathogenesis-related proteins at $500 \mu \mathrm{g} \mathrm{mL}^{-1}$, indicating that (-)-terremutin (1) was significantly more phytotoxic than (-)-mellein $(\mathbf{8})$ at the same concentrations in the calli model (Ramírez-Suero et al., 2014). 


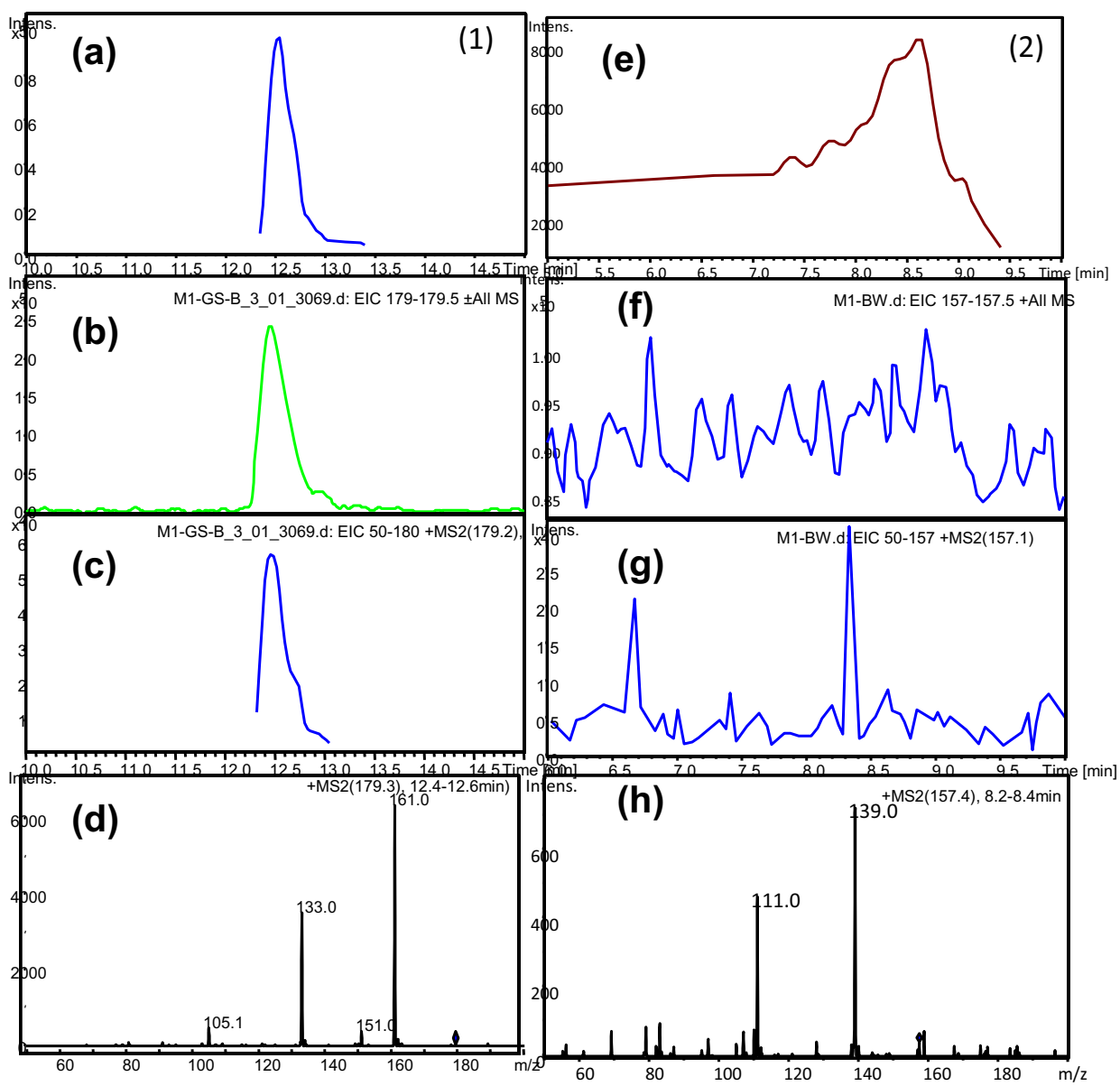

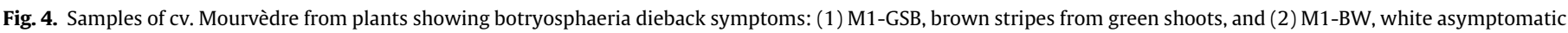

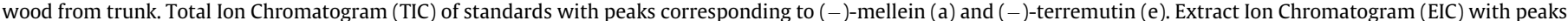

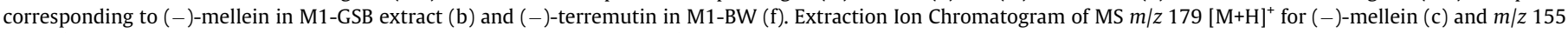

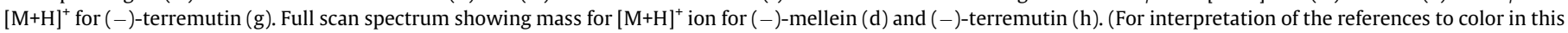
figure legend, the reader is referred to the web version of this article.)

\subsection{Analysis of the wood of grapevine plants showing botryosphaeria dieback}

Finally, to determine whether the identified phytotoxins are produced by the fungi in planta, we analysed the infected wood from four vineyards plants. The trunk wood and green shoots from plants showing esca and/or botryosphaeria dieback foliar symptoms on grapevines cv. Chardonnay (Avize, Epernay, Champagne-Ardenne region, France) and Mourvèdre (Rodilhan, Nîmes, Languedoc Roussillon region, France) were considered in the analysis. The wood samples, namely brown-striped and asymptomatic wood samples from plants showing botryosphaeria dieback symptoms (Spagnolo et al., 2014a,b) and black-streaked and asymptomatic wood trunk samples from plants showing esca symptoms (Magnin-Robert et al., 2014), were analysed separately based on the observed symptoms. The analysis was performed for (-)-terremutin (1) and (-)-mellein (8), which were considered representatives of two of the isolated chemical families. For an unambiguous identification of the compounds, the analysis was performed through HPLC-DAD-MS ${ }^{n}$ methods using a relatively high amount of wood powder from 0.2 to $3 \mathrm{~g}$ (Fig. 4). In cV. Mourvèdre, both phytotoxins were detected in the brown-striped, black-streaked and asymptomatic wood samples from the trunk and green shoots. Furthermore, in the green shoots, (-)-mellein (8) was present at a level ( $2.12 \mathrm{ng} \mathrm{mg}^{-1}$ of wood) that could be easily identified by its UV spectrum. In cv. Chardonnay, (-)-mel- lein (8) was identified in the brown-striped and black-streaked wood only (Table 2). The presence of (-)-mellein (8) in wood from plant showing esca symptoms confirmed the presence of Botryosphaeriaceae sp., as reported by Magnin-Robert et al. (2014).

Epoxide-containing compounds are able to directly form stable adducts with proteins containing thiol or phenol groups under mild experimental conditions. Thiols play a major role in maintaining the redox state of cells (homeostasis) and in the activity of an important part of enzymes that catalyse redox reactions, similarly to enzymes implicated in an antioxidant system. Two proteomicbased studies described the responses in woody tissues from fieldgrown grapevines (Magnin-Robert et al., 2014; Spagnolo et al., 2014b) and described the differential perturbations (at the protein and transcript levels) of the detoxification systems: glutathioneS-transferase (Cummins et al., 2011), peroxiredoxins (Tripathi et al., 2009), and epoxide hydrolase (Mowbray et al., 2006). These responses may indicate the presence and the activity of these toxins in woody tissues, leading to disruption of antioxidant systems.

Finally, the reduced number of samples considered in the analysis does not allow drawing a clear conclusive picture, but this manuscript constitutes the first report of phytotoxins from $N$. parvum in plants showing esca or botryosphaeria dieback in vineyards. (-)-Mellein (8) has been reported to be produced in vivo by $D$. seriata when grown on powder of grapevine wood (Djoukeng et al., 2009). Further studies are required to determine the concentration causing the observed symptoms before drawing 
Table 2

Identification of (-)-terremutin (1) and (-)-mellein (8) in grapevine wood.

\begin{tabular}{|c|c|c|c|c|}
\hline $\begin{array}{l}\text { Sample } \\
\text { name }\end{array}$ & Dry weight $(\mathrm{g})$ & Description, wood origin & $\begin{array}{l}\text { Terremutin } m / z 155[\mathrm{M}+\mathrm{H}]^{+} \mathrm{MS}^{2} \\
138,115,110\end{array}$ & $\begin{array}{l}\text { Mellein } m / z 179[\mathrm{M}+\mathrm{H}]^{+} \mathrm{MS}^{2} 161 \text {, } \\
\text { 151, 133, } 105\end{array}$ \\
\hline $\mathrm{CH} 1-\mathrm{BB}$ & 3.5 & $\begin{array}{l}\text { Brown-striped wood from trunk of plant showing } \\
\text { botryosphaeria dieback cv. Chardonnay }\end{array}$ & + & + \\
\hline $\mathrm{CH} 1-\mathrm{BW}$ & 3.0 & $\begin{array}{l}\text { White asymptomatic wood from trunk of plant } \\
\text { showing botryosphaeria dieback cv. Chardonnay }\end{array}$ & + & nd \\
\hline $\mathrm{CH}-2-\mathrm{TSB}$ & 0.2 & $\begin{array}{l}\text { Black-streaked trunk wood of plant showing leaf } \\
\text { discoloration cv. Chardonnay }\end{array}$ & + & + \\
\hline CH2-TSW & 0.2 & $\begin{array}{l}\text { White asymptomatic trunk wood of plant showing } \\
\text { leaf discoloration } \mathrm{cv} \text {. Chardonnay }\end{array}$ & nd & nd \\
\hline $\mathrm{CH} 3-\mathrm{TSB}$ & 0.2 & $\begin{array}{l}\text { Black-streaked trunk wood of plant showing }<50 \% \\
\text { leaf discoloration cv. Chardonnay }\end{array}$ & + & + \\
\hline CH3-TSW & 0.2 & $\begin{array}{l}\text { White asymptomatic trunk wood from plant } \\
\text { showing }<50 \% \text { of leaf discoloration cv. Chardonnay }\end{array}$ & nd & nd \\
\hline M1-BB & 0.5 & $\begin{array}{l}\text { Brown-striped wood from trunk of plant showing } \\
\text { botryosphaeria dieback cv. Mourvèdre }\end{array}$ & + & ++ \\
\hline M1-BW & 1.5 & $\begin{array}{l}\text { White asymptomatic wood from trunk of plant } \\
\text { showing botryosphaeria dieback cv. Mourvèdre }\end{array}$ & + & + \\
\hline M1-GSB & 2.0 & $\begin{array}{l}\text { Brown stripes from green shoots of plant showing } \\
\text { botryosphaeria dieback cv. Mourvèdre }\end{array}$ & + & +++ \\
\hline
\end{tabular}

+Traces of the signal identified only by MS, ++ and +++ signals identified by MS and UV, respectively.

a conclusion regarding the contribution of the phytotoxins to the symptoms of the disease.

\section{Conclusion}

In conclusion, this study showed (i) that $N$. parvum is able to produce a diverse variety of phytotoxins that confer high flexibility to the fungus that allows it to adapt to several environmental conditions, (ii) the evidence that genes for secondary metabolites are highly conserved in N. parvum of grapevine, (iii) the ability of the plants to respond to fungal toxins, and (iv) the presence of two of the toxins in grapevine wood from plants showing botryosphaeria dieback symptoms.

The role of these toxins on disease expression, their toxicity against other life forms and their biological functions remain to be elucidated.

\section{Experimental section}

\subsection{General experimental procedure}

The ${ }^{1} \mathrm{H}$ and ${ }^{13} \mathrm{C}$ NMR spectra were recorded either on a Bruker $360 \mathrm{MHz}$ or Bruker Avance 500 spectrometer (500 MHz) (Fällanden, Switzerland). The chemical shifts were referenced to TMS. The circular dichroism spectra were recorded on a JASCO PFD 350L spectropolarimeter. The optical rotations were determined using a Perkin-Elmer 241 digital polarimeter with a 1-dm cell. The IR spectra were obtained with a Perkin Elmer $1720 \times$ spectrometer. Electrospray mass spectrometry (ESIMS) was performed on a Bruker Daltonics Esquire HCT MS spectrometer, and HRESI-MS was performed on a Bruker FTMS 4.7T BioAPEX II.

\subsection{Analytical conditions}

Qualitative and quantitative analyses were performed by highperformance liquid chromatography equipped with a quaternary pump P100A coupled to an Ultimate 3000 diode array detector (Dionex, Thermo Scientific, Olten, Switzerland). The samples were injected onto a MN Nucleosil C18 analytical column $(250 \times 4 \mathrm{~mm}$ i.d., 100-5) (Machery-Nagel, Duren, Germany) using a flow rate of $0.7 \mathrm{~mL} \mathrm{~min}^{-1}$ at $27^{\circ} \mathrm{C}$. The mobile phase consisted of solvent $\mathrm{A}$ (water: $0.5 \%$ formic acid) and solvent $\mathrm{B}$ (acetonitrile); the gradient system was initiated with $5 \%$ of solvent B for 2 min and reached $40 \%$ at $16 \mathrm{~min}, 70 \%$ at $30 \mathrm{~min}$ and $100 \%$ at $45 \mathrm{~min}$. The toxins were detected at 270, 260, 240 and $314 \mathrm{~nm}$ with diode array online detection. The UV spectra were recorded between 200 and $600 \mathrm{~nm}$.

The LC-MS ${ }^{n}$ analyses were performed under the same conditions as before on a LC-DAD Waters 2695 instrument coupled to a Bruker Daltonics Esquire HCT MS spectrometer. The toxins were identified according to their retention time (Rt), $m / z$ and $\mathrm{MS}^{n}$ spectra. The voltage was set to $3820 \mathrm{~V}$, and the conditions were the following: nebulizer, $15 \mathrm{psi} ; \mathrm{N}_{2}$ flow, $12 \mathrm{~L} \mathrm{~min}^{-1}$; and dry temperature, $320^{\circ} \mathrm{C}$. The mass spectra were recorded between 50 and $500 \mathrm{~m} / z$. For all analysis, total ion chromatogram was recorded with auto $\mathrm{MS}^{2}$ for (-)-terremutin (1) $\mathrm{m} / \mathrm{z} 157$ and (-)-mellein (8) $m / z 179$ in the positive ionisation mode.

The purification of compounds by HPLC was performed on a C18 Ascentis column ( $5 \mu \mathrm{m}, 15 \times 10 \mathrm{~mm}$; Supelco, Bellefonte, PA, USA) at the flow rate of $1.5 \mathrm{~mL} \cdot \mathrm{mn}^{-1}$. Three different purification solvent gradients were used: gradient I composed of $\mathrm{MeOH} / \mathrm{H}_{2} \mathrm{O}$ starting at $50 \% \mathrm{MeOH}$ and reaching $100 \%$ in $18 \mathrm{~min}$, gradient II of $\mathrm{ACN} /\left(\mathrm{H}_{2} \mathrm{O}: 0.5 \%\right.$ formic acid $)$ starting at $20 \%$ acetonitrile and reaching $100 \%$ in $18 \mathrm{~min}$, and gradient III of $\mathrm{ACN} /\left(\mathrm{H}_{2} \mathrm{O}: 0.5 \%\right.$ formic acid) starting at $5 \%$ acetonitrile to $20 \%$ in $20 \mathrm{~min}$.

\subsection{Fungal growth, culture medium and screening}

Seven N. parvum isolates from the collection of the IFV (Institut Français de la Vigne et du Vin, Rodilhan, France) from grapevine plants showing decline that were collected from vineyards and nurseries and identified according to Van Niekerk et al. (2004) and six strains from a single spore collection of the Instituto Superior de Agronomia (Universidade de Lisboa, Portugal) isolated from plants showing esca and/or BDA identified by microscopy and molecular methods, such as ISSR fingerprinting according to Van Niekerk et al., 2004 and Zhou et al., 2001, were used in this study (Table 1). The fungi were maintained on potato dextrose agar (PDA Difco, Detroit, MI, USA). Ten replicates of each strain were incubated at $28{ }^{\circ} \mathrm{C}$ in the dark for 14 days. N. parvum cultures from Petri dishes (90 $\mathrm{mm} \varnothing)$ were extracted separately with $5 \%$ methanol in ethyl acetate $(3 \times 500 \mathrm{~mL})$, and the solvent was evaporated under reduced pressure to dryness. An aliquot was dissolved in $\mathrm{MeOH}$ to a concentration of $1 \mathrm{mg} \mathrm{mL}^{-1}$ for LC-DAD analysis, and $50 \mu \mathrm{L}$ were subjected to HPLC analysis under the analytical conditions described in Section 4.2. 
The peak areas at a specific wavelength were chosen for quantification: $\mu_{\max } 260 \mathrm{~nm}$ for dihydrotoluquinones and $313 \mathrm{~nm}$ for dihydroisocoumarins. For the seven compounds that were analysed through a leaf disc assay to determine their phytotoxic activity, quantification was performed using external standard calibration methods. The data are reported as $\mu \mathrm{g} \mathrm{mg}^{-1}$ of crude extracts (Supplementary Fig. S1).

\subsection{Extraction and purification of phytotoxins}

The isolate Bourgogne 2S-16 (Bourg) was cultured on 100 PDA Petri dishes $(90 \mathrm{~mm} \emptyset)$. The plates were individually inoculated with 4-mm agar discs of 7-day-old cultures and incubated at $28^{\circ} \mathrm{C}$ in the dark for 14 days. $N$. parvum plates were extracted with EtOAc/MeOH $(95: 5 ; \mathrm{v} / \mathrm{v})(3 \times 1000 \mathrm{~mL})$, which, after solvent evaporation, yielded $1.936 \mathrm{~g}$ of crude extract. This extract was then dissolved in water and successively extracted with hexane and chloroform/MeOH $(1: 1 ; \mathrm{v} / \mathrm{v})$, leading to three extracts, namely hexane (378 $\mathrm{mg}$ ), methanol (1.3019 g) and aqueous (256 mg) extracts. Dilution with chloroform of the concentrated methanol extract led to the formation of a precipitate that, after filtration, afforded $133 \mathrm{mg}$ of (-)-terremutin (1). The filtrate was concentrated, submitted to $\mathrm{SiO}_{2}$ flash column chromatography and eluted with a stepwise gradient of $n$-hexane in $50-100 \%$ AcOEt, yielding six fractions. Fraction $2(21 \mathrm{mg})$ was further purified by HPLC with gradient I (Section 4.2), which led to the isolation of $5 \mathrm{mg}$ of $(3 R, 4 R)$-4-hydroxymellein (9) and $6 \mathrm{mg}$ of $(3 R, 4 S)$-4-hydroxymellein (10). Fractions $4(33.4 \mathrm{mg})$ and $5(35 \mathrm{mg})$ were purified by HPLC (gradient II) (Section 4.2) leading to the isolation of $10 \mathrm{mg}$ of (+)-asperlin (6), $8.8 \mathrm{mg}$ of (6R,7S)-dia-asperlin (7), $4.7 \mathrm{mg}$ of $(R)$-3-hydroxymellein (11), $1 \mathrm{mg}$ of 2-hydroxy propyl salicylic acid (12), and $4.6 \mathrm{mg}$ of (+)-epi-shpaeropsidone (6).

The aqueous extract $(256 \mathrm{mg}$ ) was purified by HPLC (gradient III) (Section 4.2) and led to the isolation of $8 \mathrm{mg}$ of (-)-terremutin (1), $7 \mathrm{mg}$ of (-)-terremutin hydrate (2), $11 \mathrm{mg}$ of 4-chloro-3,5,6trihydroxy-2-methylcyclohexan-2-enone or 4-chloro-terremutin hydrate (4), and $1.5 \mathrm{mg}$ of 4-hydroxysuccinate-terremutin hydrate (5). Finally, the $n$-hexane extract ( $378 \mathrm{mg}$ ) was submitted to $\mathrm{SiO}_{2}$ flash column chromatography and eluted with a stepwise gradient of $100 \%$ hexane to $100 \%$ AcOEt to obtain eight fractions. Fractions 2 and 6 were further purified by HPLC (gradient I) and led to the isolation of $12 \mathrm{mg}$ of (-)-mellein (8), $2 \mathrm{mg}$ of $(3 R, 4 R)$-4-hydroxymellein (9) and $7 \mathrm{mg}$ of $(3 R, 4 S)$-4-hydroxymellein (10).

\subsubsection{Metabolites isolated from N. parvum culture}

(-)-Terremutin (1): brownish powder, $140 \mathrm{mg}$, Rt 8.8. CD (c $1 \times 10^{-3} \mathrm{M}$, ethanol $)[\phi]^{25}(\mathrm{~nm})-199.8 \quad(310 \mathrm{~nm}), \quad-57.5$ (265 nm), $[\alpha]_{\mathrm{D}}^{25}-200\left(\mathrm{c} 1 \times 10^{-2}\right)$. IR $\lambda_{\max } \mathrm{cm}^{-1} 3297,3095,1623$, 1394, 1340, 1278, 1251; UV (MeOH) $\lambda_{\max } 274 \mathrm{~nm} .{ }^{1} \mathrm{H}$ NMR $(400 \mathrm{MHz}, \mathrm{MeOD}) \delta_{\mathrm{H}} 4.48(\mathrm{~d}, J=0.7 \mathrm{~Hz}, 1 \mathrm{H}), 3.63(\mathrm{dd}, J=3.7 \mathrm{~Hz}$, $J=1.3 \mathrm{~Hz}, 1 \mathrm{H}), 3.39$ (dd, $J=3.7 \mathrm{~Hz}, J=1.1 \mathrm{~Hz}, 1 \mathrm{H}), 1.67(\mathrm{~s}, 3 \mathrm{H}) \cdot{ }^{13} \mathrm{C}$ NMR $(100 \mathrm{MHz}, \mathrm{MeOD}) \delta_{\mathrm{C}} 193.4,171.5,109.2,66.4,55.6,52.6,7.4$. EI-MS $m / z(\%): 155.9[\mathrm{M}]^{+}$(30), 137.9 (7), 126.9 (23), 109.9 (51), 82.9 (38), 70.9 (90), 56.0 (98), 43.0 (69), 28.0 (100). ESI-MS m/z $153[\mathrm{M}-\mathrm{H}]^{-}$calcd for $\mathrm{C}_{7} \mathrm{H}_{8} \mathrm{O}_{4}$.

(+)-Terremutin hydrate (2): white powder, $6.5 \mathrm{mg}$, Rt 5.03 . $[\alpha]_{\mathrm{D}}^{25}+300\left(\mathrm{c} 1 \times 10^{-2}\right) .{ }^{1} \mathrm{H}$ NMR $\left(360 \mathrm{MHz}, \mathrm{D}_{2} \mathrm{O}\right) \delta 4.22(\mathrm{~d}$, $J=9.5 \mathrm{~Hz}, 2 \mathrm{H}), 3.63(\mathrm{t}, J=9.5 \mathrm{~Hz}, 1 \mathrm{H}), 1.65(\mathrm{~s}, 3 \mathrm{H}) .{ }^{13} \mathrm{C} \mathrm{NMR}$ $\left(125 \mathrm{MHz}, \mathrm{D}_{2} \mathrm{O}\right) \delta 185.0,172.5,110.1,76.5,73.4(2 \mathrm{xC}), 7.4$. IR $v_{\max }$ $\mathrm{cm}^{-1}$ 3250, 1612; UV (MeOH) $\lambda_{\max } 261 \mathrm{~nm}$; ESI-MS $m / z=175.1$ $[\mathrm{M}+\mathrm{H}]^{+}$calcd for $\mathrm{C}_{7} \mathrm{H}_{10} \mathrm{O}_{5}$.

(+)-Epi-sphaeropsidone (3): colourless powder, $4.6 \mathrm{mg}$, Rt 9.2. CD (c $1 \times 10^{-3} \mathrm{M}$, ethanol) $[\phi]^{25}(\mathrm{~nm})+25.0(338 \mathrm{~nm}),-14(266 \mathrm{~nm})$; $[\alpha]_{\mathrm{D}}^{25}+210$ (c 0.03$) ;{ }^{1} \mathrm{H}$ NMR $\left(400 \mathrm{MHz}, \mathrm{CDCl}_{3}\right) \delta_{\mathrm{H}} 5.26$ (d, $J=1.5 \mathrm{~Hz}, 1 \mathrm{H}), 4.67$ (b, $1 \mathrm{H}), 3.73(\mathrm{~s}, 3 \mathrm{H}), 3.73(\mathrm{dd}, J=3.5 \mathrm{~Hz}$, $J=1.3 \mathrm{~Hz}, 1 \mathrm{H}), 3.44(\mathrm{dt}, J=3.5 \mathrm{~Hz}, J=1.3 \mathrm{~Hz}, 1 \mathrm{H}), 2.92$ (b, $1 \mathrm{H}) \cdot{ }^{13} \mathrm{C}$
NMR (100 MHz, $\left.\mathrm{CDCl}_{3}\right) \delta_{\mathrm{C}} 193.2,172.1,99.1,65.6,56.4,54.5,52.2$. $v_{\max } \mathrm{cm}^{-1} 3378,1658,1620$; UV (MeOH) $\lambda_{\max } 262 \mathrm{~nm}$; ESI-MS $\mathrm{m} / z$ $155.1[\mathrm{M}-\mathrm{H}]^{-}$calcd for $\mathrm{C}_{7} \mathrm{H}_{8} \mathrm{O}_{4}$.

(-)-4-Chloro-3,5,6-trihydroxy-2-methylcyclohex-2-enone or 4chloro-terremutin hydrate (4): red powder, $16 \mathrm{mg}$, Rt 8.0 (c $1 \times 10^{-3} \mathrm{M}$, ethanol) $[\phi]^{25}(\mathrm{~nm})-35.3(272 \mathrm{~nm}),-29.8(266 \mathrm{~nm})$. $[\alpha]_{\mathrm{D}}^{25}-210$ (c 0.01$) .{ }^{1} \mathrm{H} \quad \mathrm{NMR} \quad\left(400 \mathrm{MHz}, \mathrm{D}_{2} \mathrm{O}\right) \delta_{\mathrm{H}} 4.74(\mathrm{~d}$, $J=10.3 \mathrm{~Hz}, 1 \mathrm{H}), 4.41(\mathrm{~d}, J=9.3 \mathrm{~Hz}, 1 \mathrm{H}), 3.90(\mathrm{t}, J=9.8 \mathrm{~Hz}, 1 \mathrm{H}), 1.74$ (s, 3H). ${ }^{13} \mathrm{C}$ NMR $\left(125 \mathrm{MHz}, \mathrm{D}_{2} \mathrm{O}\right) \delta_{\mathrm{C}} 184.8,179.4,111.3,76.4,72.6$, 64.7, 8.1. UV (MeOH) $\lambda_{\max } 264 \mathrm{~nm}$. HRESI-MS 215.0082 [M+Na]+ calcd 215.0082 for $\mathrm{C}_{7} \mathrm{H}_{9} \mathrm{ClO}_{4}$.

(+)-3-((2,5,6-Trihydroxy-3-methyl-4-oxocyclohex-2-enyloxy)carbonyl)propanoic acid or 4-hydroxysuccinate-terremutin hydrate (5): white powder, $2 \mathrm{mg}$, Rt 12.2. CD $\left(c 1 \times 10^{-3} \mathrm{M}\right.$, ethanol $)[\phi]^{25}$ $(\mathrm{nm})+20.7(278 \mathrm{~nm}),-30.46(265 \mathrm{~nm}),[\alpha]_{\mathrm{D}}^{25}+170(c 0.03) .{ }^{1} \mathrm{H}$ NMR $\left(500 \mathrm{MHz}, \mathrm{D}_{2} \mathrm{O}\right) \quad \delta_{\mathrm{H}} 5.47(\mathrm{~d}, J=10.2 \mathrm{~Hz}, 1 \mathrm{H}), 4.46(\mathrm{~d}$, $J=9.3 \mathrm{~Hz}, 1 \mathrm{H}), 3.99(\mathrm{t}, J=9.4 \mathrm{~Hz}, 1 \mathrm{H}), 2.88(\mathrm{t}, J=6.4 \mathrm{~Hz}, 2 \mathrm{H}), 2.76$ $(\mathrm{t}, J=6.6 \mathrm{~Hz}, 2 \mathrm{H}), 1.71(\mathrm{~s}, 3 \mathrm{H}) .{ }^{13} \mathrm{C}$ NMR $\left(125 \mathrm{MHz}, \mathrm{D}_{2} \mathrm{O}\right) \delta_{\mathrm{C}} 187.8$, 178.4, 177.3, 174.6, 110.7, 76.4, 74.0, 72.1, 29.3 (2xC), 7.5; ESI-MS $m / z=297.0[\mathrm{M}+\mathrm{Na}]^{+}, 275.1[\mathrm{M}+\mathrm{H}]^{+}$.

(+)-Asperlin (6): colourless powder, $7.2 \mathrm{mg}$, Rt 15.7. CD (c $1 \times 10^{-3} \mathrm{M}$, ethanol) $[\phi]^{25}(\mathrm{~nm})+29.5(277 \mathrm{~nm})-8.3(265 \mathrm{~nm})$; $[\alpha]_{\mathrm{D}}^{25}+210(c \quad 0.03) .{ }^{1} \mathrm{H}$ NMR $\left(360 \mathrm{MHz}, \mathrm{CDCl}_{3}\right) \delta_{\mathrm{H}} 7.07$ (dd, $J=9.7 \mathrm{~Hz}, J=5.7 \mathrm{~Hz}, 1 \mathrm{H}), 6.22(\mathrm{~d}, J=10.0 \mathrm{~Hz}, 1 \mathrm{H}), 5.31$ (dd, $J=5.9 \mathrm{~Hz}, J=2.7 \mathrm{~Hz}, 1 \mathrm{H}), 4.10(\mathrm{dd}, J=7.3 \mathrm{~Hz}, J=2.7 \mathrm{~Hz}, 1 \mathrm{H}), 3.11-$ $3.05(\mathrm{~m}, 2 \mathrm{H}), 2.14(\mathrm{~s}, 3 \mathrm{H}), 1.39(\mathrm{~d}, J=5.0 \mathrm{~Hz}, 3 \mathrm{H}) \cdot{ }^{13} \mathrm{C} \mathrm{NMR}$ $\left(125 \mathrm{MHz}, \mathrm{CDCl}_{3}\right) \delta_{\mathrm{C}} 169.9,161.6,140.6,125.0,79.1,62.3,55.1$, 54.8, 20.7, 17.2. IR $v_{\max } \mathrm{cm}^{-1} 1747,1720, \mathrm{UV}(\mathrm{MeOH}), \lambda_{\max }$ $229 \mathrm{~nm}$. ESI-MS (+) m/z $235.3[\mathrm{M}+\mathrm{Na}]^{+}$for $\mathrm{C}_{10} \mathrm{H}_{12} \mathrm{O}_{5} \mathrm{Na}$.

(+)-(6R, 7S)-dia asperlin (7): colourless powder, $8.8 \mathrm{mg}$, Rt 14.7. $\mathrm{CD}\left(\right.$ c $0.3 \times 10^{-3} \mathrm{M}$, ethanol) $[\phi]^{25}(\mathrm{~nm})+3.7(277 \mathrm{~nm}),-20.0$ $(265 \mathrm{~nm}),[\alpha]_{\mathrm{D}}^{25}+266$ (c 0.09). ${ }^{1} \mathrm{H}$ NMR $\left(500 \mathrm{MHz}, \mathrm{CDCl}_{3}\right) \delta_{\mathrm{H}} 6.86$ (dd, $J=9.9 \mathrm{~Hz}, J=5.2 \mathrm{~Hz}, 1 \mathrm{H}), 6.22(\mathrm{~d}, J=9.6 \mathrm{~Hz}, 1 \mathrm{H}), 5.51(\mathrm{t}$, $J=3.9 \mathrm{~Hz}, 1 \mathrm{H}), 4.36(\mathrm{t}, J=3.6 \mathrm{~Hz}, 1 \mathrm{H}), 3.05(\mathrm{qd}, J=5.0 \mathrm{~Hz}, J=2.2 \mathrm{~Hz}$, $1 \mathrm{H}), 3.01(\mathrm{dd}, J=5.0 \mathrm{~Hz}, J=2.2 \mathrm{~Hz}, 1 \mathrm{H}), 2.15(\mathrm{~s}, 3 \mathrm{H}), 1.35$ (d, $J=5.2 \mathrm{~Hz}, 3 \mathrm{H}) .{ }^{13} \mathrm{C}$ NMR $\left(125 \mathrm{MHz}, \mathrm{CDCl}_{3}\right) \delta_{\mathrm{C}} 170.0,161.5,139.8$, 125.1, 78.2, 63.0, 56.7, 50.6, 20.7, 17.1. IR (film) $v_{\max } \mathrm{cm}^{-1} 1745$, 1725, UV (MeOH) $\lambda_{\max } 229 \mathrm{~nm}$ HR-MS $235.0576\left(\mathrm{C}_{10} \mathrm{H}_{12} \mathrm{O}_{5}+\mathrm{Na}^{+}\right.$ calcd 235.0577).

(-)-Mellein (8): colourless, $12 \mathrm{mg}$, Rt 24.8. CD ( c $0.3 \times 10^{-3} \mathrm{M}$, ethanol) $[\phi]^{25}(\mathrm{~nm})-34.87(266 \mathrm{~nm})-5.89(249 \mathrm{~nm}),-14.35$ $(233 \mathrm{~nm})[\alpha]_{\mathrm{D}}^{25}-55$ (c $\left.0.02 \mathrm{EtOH}\right),(-)-(3 R, 4 S)$-trans-4-hydroxymellein (9): colourless, $13 \mathrm{mg}$, Rt 17.96, (-)-(3R,4R)-cis-4-hydroxymellein (10): colourless, $8 \mathrm{mg}$, Rt 16.6. ${ }^{1} \mathrm{H}$ NMR $(360 \mathrm{MHz})$ and ${ }^{13} \mathrm{C}$ NMR $(125 \mathrm{MHz})$ in $\mathrm{CDCl}_{3}$ were identical to the data reported by Djoukeng et al. (2009). (-)-(R)-3-hydroxymellein (11): colourless, $4 \mathrm{mg}$, RT 18.6. CD (c $0.3 \times 10^{-3} \mathrm{M}$, ethanol) $[\phi]^{25}(\mathrm{~nm})-13.74$ $(270 \mathrm{~nm}),-21.25(254 \mathrm{~nm}),-35.06(234 \mathrm{~nm})[\alpha]_{\mathrm{D}}^{25}-55$ (c 0.02 EtOH). ${ }^{1} \mathrm{H}$ NMR $\left(500 \mathrm{MHz}, \mathrm{CDCl}_{3}\right) \delta_{\mathrm{H}} 10.98(\mathrm{~s}, 1 \mathrm{H}), 7.44(\mathrm{t}$, $J=8.0 \mathrm{~Hz}, 1 \mathrm{H}), 6.92(\mathrm{~d}, J=8.5 \mathrm{~Hz}, 1 \mathrm{H}), 6.74(\mathrm{~d}, J=7.4 \mathrm{~Hz}, 1 \mathrm{H}), 3.26$ (d, $J=16.4 \mathrm{~Hz}, 2 \mathrm{H}), 3.16$ (d, $J=16.2 \mathrm{~Hz}, 1 \mathrm{H}), 1.78$ (s, 3H). ${ }^{13} \mathrm{C}$ NMR $\left(125 \mathrm{MHz}, \mathrm{CDCl}_{3}\right) \delta_{\mathrm{C}} 169.1,161.9,140.9,136.6,119.0,116.7,105.2$, 107.2, 38.6, 28.5. UV (MeOH) $\lambda_{\max } 246$ and $313 \mathrm{~nm}$. HR-ESIMS (+) 217.0476 $\left(\mathrm{C}_{10} \mathrm{H}_{10} \mathrm{O}_{4}+\mathrm{Na}^{+}\right.$calcd 217.0471).

6-Methylsalicylic acid or 2-hydroxy-6-methylbenzoic acid (12): colourless product, $2 \mathrm{mg}$, RT $21.2{ }^{1} \mathrm{H}$ NMR $\left(360 \mathrm{MHz}, \mathrm{CD}_{3} \mathrm{OD}\right) \delta_{\mathrm{H}}$ $7.25(\mathrm{t}, J=7.7 \mathrm{~Hz}, 1 \mathrm{H}), 6.76(\mathrm{~d}, J=7.3 \mathrm{~Hz}, 1 \mathrm{H}), 6.74(\mathrm{t}, J=7.7 \mathrm{~Hz}$, $1 \mathrm{H}), 2.84(\mathrm{~s}, 3 \mathrm{H}) .{ }^{13} \mathrm{C}$ NMR $\left(125 \mathrm{MHz}, \mathrm{CD}_{3} \mathrm{OD}\right) \delta_{\mathrm{C}} 172.9,162.4$, $140.2,134.3,123.8,116.2,110.71,23.8$. UV $(\mathrm{MeOH}) \lambda_{\max } 243$ and $307 \mathrm{~nm}$. ESI-MS $m / z 151[\mathrm{M}-\mathrm{H}]^{-}$.

6-(2-Hydroxypropnyl)-salicylic acid also named flemingipanic acid (13): colourless, $1 \mathrm{mg}$, RT 15.6. ${ }^{1} \mathrm{H}$ NMR $\left(360 \mathrm{MHz}, \mathrm{CDCl}_{3}\right) \delta_{\mathrm{H}} 5.90$ (broad band, $1 \mathrm{H}), 7.26(\mathrm{t}, J=8.1 \mathrm{~Hz}, 1 \mathrm{H}), 6.82(\mathrm{~d}, J=8.1 \mathrm{~Hz}, 1 \mathrm{H})$, $6.66(\mathrm{~d}, J=7.3 \mathrm{~Hz}, 1 \mathrm{H}), 4.13(\mathrm{~m}, 1 \mathrm{H}), 3.09(\mathrm{dd}, J=8.2,10.9 \mathrm{~Hz}$, $1 \mathrm{H}), 2.88(\mathrm{dd}, J=4.5,9.0 \mathrm{~Hz}, 1 \mathrm{H}), 1.29(\mathrm{~d}, J=6.3 \mathrm{~Hz}, 3 \mathrm{H}) .{ }^{13} \mathrm{C} \mathrm{NMR}$ $\left(125 \mathrm{MHz}, \mathrm{CDCl}_{3}\right) \quad \delta_{\mathrm{C}} 172.98,162.5,140.23,134.28,123.24$, 
116.80, 110.71, 71.14, 43.76, 23.71. UV (MeOH) $\lambda_{\max } 243$ and $303 \mathrm{~nm}$. ESIMS $m / z[\mathrm{M}-\mathrm{H}]^{-} 195$.

\subsection{Phytotoxic assays}

\subsubsection{Grapevine leaf disc assays}

Three nodes of Chardonnay cuttings were collected during winter and disinfected for $4 \mathrm{~h}$ in cryptonol $(0.05 \%)$ at $28^{\circ} \mathrm{C}$. After six weeks of storage at $4{ }^{\circ} \mathrm{C}$ in the dark, the cuttings were rehydrated through a second period of disinfection in cryptonol (0.05\%) for one night at $28^{\circ} \mathrm{C}$. The cuttings were plunged into indolebutyric acid (IBA, $1.0 \mathrm{~g} / \mathrm{L}$ ) to stimulate root growth, planted in large pots and maintained under greenhouse conditions (with natural light). After 3 months of growth, grapevine leaves were cut into discs with diameters of $5 \mathrm{~mm}$ with a cork borer and immersed in $1 \mathrm{~mL}$ of the phytotoxic solutions in 24-well plates. The fungal crude extracts or pure compounds were dissolved in $2 \%$ ethanol solution at the concentrations of $500 \mu \mathrm{g} \mathrm{mL}^{-1}$ for crude extracts and 200 and $100 \mu \mathrm{g} \mathrm{mL}^{-1}$ for pure compounds. The phytotoxicity was evaluated by measuring the relative percentage of the necrotic area after 24 and $48 \mathrm{~h}$. The reference control was a solution of $2 \%$ ethanol. For the assays with pure compounds, only the seven major compounds were tested, i.e., (-)-terremutin (1), (+)-epi-sphaeropsidon (3), (+) -(6R, 7S)-dia- asperlin (7), (-)-mellein (8), (-)-(3R,4S)-trans-4hydroxymellein (9), (-)-(3R,4R)-cis-4-hydroxymellein (10) and $(-)-(R)$-3-hydroxymellein (11). The results are the means from two experiments with three leaves at each concentration (a total of six leaves). The images were saved as TIFF files and processed for necrosis quantification using Image J version $1.45(\mathrm{NIH})$. The software settings were the same for every image analysed, and the brown-coloured area corresponding to necrosis formation is expressed in pixels.

\subsubsection{Calli assay, RNA extraction and gene expression analysis by real-} time quantitative RT-PCR

Calli were harvested in liquid nitrogen $0,1,3$ and 6 days after being subcultured on medium supplemented with terremutin (1) at two concentrations ( 25 and $200 \mu \mathrm{g} \mathrm{mL}^{-1}$ ) and stored at $-80^{\circ} \mathrm{C}$. Total RNA extraction and transcripts analysis were performed as described by Ramírez-Suero et al. (2014). The primers listed in the manuscript published by Ramírez-Suero et al. (2014) were designed for the amplification of genes associated with cellular detoxification ( $V v G S T 1$ and $V v S O D)$, the jasmonic acid pathway ( $V v A O S$ and $V v L O X$ ), the synthesis of secondary metabolites and phytoalexins through the phenylpropanoid pathway ( $V v P A L$ and $V v S T S 1)$, and the flavonoid pathway ( $V v F 3 H$ and $V v F M T$ ) and encoding pathogenesis-related proteins ( $V v P R 6, V v G L U, V v C H I T 4 c$, and VvPR10.1).

The data were analysed using the CFXManager software, and the relative levels of gene expression were determined following the method reported by Hellemans et al. (2007) using VvACT and $V v E F 1-C S$ as the housekeeping genes. Each data point represents the mean from three technical and two biological replicates. The error bars represent the standard errors of the mean. Significant differential gene expression was defined with an induction ratio higher than 4 .

\subsection{Analysis of grapevine wood}

Four samples of grapevine trunk showing esca and/or botryosphaeria dieback symptoms were selected for analysis. Three samples were obtained from cv. Chardonnay isolated from Avize in the Champagne area (France) in 2012 from the trunk of a plant that (Spagnolo et al., 2014a,b) (i) showed botryosphaeria dieback the previous year [CH1-BB (brown-striped wood from trunk) and CH1-BW (white asymptomatic wood from trunk)], (ii) showed the beginning of apoptosis and leaf discoloration considered esca proper [CH2-TSB (black-streaked trunk wood) and $\mathrm{CH} 2-\mathrm{TSW}$ (white asymptomatic wood from trunk)] (Magnin-Robert et al., 2014) and (iii) showing leaf discoloration less than 50\% [CH3-TSB (black-streaked trunk wood) and CH3-TSW (white asymptomatic wood from trunk)]. One plant of cv. Mourvèdre, which was collected from Rodilhan, Nîmes area (France) in 2009, showed botryosphaeria dieback symptoms in the current year [M1-BB (brown-striped trunk wood) and M1-BW (white asymptomatic wood from trunk wood)], and another sample was obtained from infected green shoots [M1-GSB (brown-striped green shoots)] (Table 2). The exfoliating bark was peeled off, and brown stripes were isolated using a drill. Wood powder $(3 \mathrm{~g})$ was extracted three times with $1 \mathrm{~mL}$ of $\mathrm{MeOH}$ for $100 \mathrm{~g}$ of powder at $40^{\circ} \mathrm{C}$ with agitation for $1 \mathrm{~h}$. The extracts were pooled, and the solvent was reduced under a steam of nitrogen to $5 \mathrm{~mL}$ and then extracted twice with $5 \mathrm{~mL}$ of $n$-hexane to recover mellein $(\mathbf{8})$. The $n$-hexane extracts were pooled and, after drying, were dissolved in $200 \mu \mathrm{L}$ of $\mathrm{MeOH}$ for analysis. The methanolic fraction was reduced to $200 \mu \mathrm{L}$, loaded onto a Chromabond C18 column (500 mg) (Machery-Nagel, Durren Germany), and eluted with $2 \mathrm{~mL}$ of $\mathrm{MeOH} / \mathrm{H}_{2} \mathrm{O}(15 / 85 ; \mathrm{v} / \mathrm{v})$ to recover terremutin (1). The fraction was concentrated under nitrogen to $200 \mu \mathrm{L}$ of $\mathrm{MeOH}$, and $2 \mu \mathrm{L}$ was injected into HPLC-MS ${ }^{n}$ for analysis according to the system described above (Section 4.2).

\section{Acknowledgements}

This work was supported by Grants from the Swiss Secrétariat d'Etat à la Formation, à la Recherche et à l'Innovation (SEFRI-N ${ }^{\circ}$ C08.0140), works related to COST 858 action-Viticulture - Biotic and abiotic stress - Grapevine defence mechanism and grape development, and The French Ministère de l'Agriculture, de l'Agroalimentaire et de la Forêt (CASDAR - Compte d'Affectation Spéciale au Développement Agricole et Rural AAP N7124 - V902). We thank Dr. Antony Buchala for English revision.

\section{Appendix A. Supplementary data}

Supplementary data associated with this article can be found, in the online version, at http://dx.doi.org/10.1016/j.phytochem.2015. 01.012 .

\section{References}

Argoudelis, A.D., Zieserl, J.F., 1966. The structure of U-13,933, a new antibiotic Tetrahedron Lett. 7, 1969-1973.

Asha, K.N., Chowdhury, R., Hasan, C.M., Rashid, M.A., 2004. Steroids and Polyketides from Uvaria hamiltonii stem bark. Acta Pharm. 54, 57-63.

Bertsch, C., Ramirez-Suero, M., Magnin-Robert, M., Larignon, P., Chong, J., AbouMansour, E., Spagnolo, A., Clément, C., Fontaine, F., 2013. Grapevine trunk diseases: complex and still poorly understood. Plant. Pathol. 62, 245-263.

Cabras, A., Mannoni, M.A., Serra, S., Andolfi, A., Fiore, M., 2006. Occurrence, isolation and biological activity of phytotoxic metabolites produced in vitro by Sphaeropsis sapinea, pathogenic fungus of Pinus radiata. Eur. J. Plant Pathol. $115,187-193$.

Cummins, I., Dixon, D.P., Freitag-Pohl, S., Skipsey, M., Edwards, R., 2011. Multiple roles for plant glutathione transferases in xenobiotic detoxification. Drug Metab. Rev. 43, 266-280.

Cole, R.J., Cox, R.H., 1981. Handbook of Toxic Fungal Metabolites, vol. 3. Academic Press, New York, NY, USA, 623-624.

Dewi, R.T., Tachibana, S., Itoh, K., Ilyas, M., 2012. Isolation of antioxidant compounds from Aspergillus Terreus LS01. J. Microb. Biochem. Technol. 41, 010-014.

Djoukeng, J.D., Polli, S., Larignon, P., Abou-Mansour, E., 2009. Identification of phytotoxins from Botryosphaeria obtusa, a pathogen of black dead arm disease of grapevine. Eur. J. Plant Pathol. 124, 303-308.

Evidente, A., Punzo, B., Andolfi, A., Cimmino, A., Melck, D., Luque, J., 2010. Lipophilic phytotoxins produced by Neofusicoccum parvum, a grapevine canker agent Phytopathol. Mediterr. 49, 74-79.

Evidente, A., Sparapano, L., Fierro, O., Bruno, G., Giordano, F., Motta, A., 1998 Sphaeropsidone and epi-sphaeropsidone, phytotoxic dimedone methyl ethers produced by Sphaeropsis sapinea $f$. sp. cupressi grown in liquid culture. Phytochemistry 48, 1139-1143. 
Fex, T., Wickberg, B., 1981. Structure of chaloxone, isolated from a Chalara Sp. Acta Chem. Scand. B35, 97-98.

Fujii, I., Ono, Y., Tada, H., Gomi, K., Ebizuka, Y., Sankawa, U., 1996. Cloning of the polyketide synthase gene atX from Aspergillus terreus and its identification as the 6-methylsalicylic acid synthase gene by heterologous expression. Mol. Gen. Genet. 1996 (253), 1-10.

Hellemans, J., Mortier, G., De Paepe, A., Speleman, F., Vandesompele, J., 2007. QBase relative quantification framework and software for management and automated analysis of real-time quantitative PCR data. GenomeBiol 8 (2), R19.

Hofstetter, V., Buyck, B., Croll, D., Viret, O., Couloux, A., Gindro, K., 2012. What if esca disease of grapevine were not a fungal disease? Fungal Div. 54, 51-67.

Kiriyama, N., Higushi, Y. Yamamoto, Y. 1977. Studies on the metabolic products of Aspergillus terreus. II. Structure and biosynthesis of the metabolites of the strain ATCC12238. Chem. Pharm. Bull. 25, 1265-1272.

Komai, S.-I., Hosoe, T., Nozawa, K., Okada, K., De Campos Takaki, G.M., Fukushima, K., Miyaji, M., Horie, Y., Kawai, K.I., 2003. Antifungal activity of pyranone and furanone derivatives, isolated from Aspergillus sp. IFM51759, against Aspergillus fumigatus. Mycotoxins 53, 11-17.

Larignon, P., Dubos, B., 1997. Fungi associated with esca disease in grapevine. Eur. J. Plant Pathol. 103, 147-157.

Larignon, P., Fulchic, R., Cere, L., Dubos, B., 2001. Observation on black dead arm in French vineyards. Phytopathol. Mediterr. 40, S336-S342.

Luque, J., Martos, S., Aroca, A., Raposo, R., Garcia-Figueres, F., 2009. Symptoms and fungi associated with declining mature grapevine plants in Northeast Spain. J. Plant Pathol. 91, 381-390.

Marrs, K.A., 1996. The functions and regulation of glutathione S-transferases in plants. Annu. Rev. Plant Phys. 47, 127-158.

Magnin-Robert, M., Spagnolo, A., Alayi, T.D., Cilindre, C., Mercier, L., Schaeffer-Reiss, C., Van Dorsselaer, A., Clément, C., Fontaine, F., 2014. Proteomics insights into changes in grapevine wood in response to esca proper and apoplexy. Phytopathol. Medit. 53, 168-187.

Magnin-Robert, M., Letousey, P., Spagnolo, A., Rabenoelina, F., Jacquens, L., Mercier, L., Clément, C., Fontaine, F., 2011. Leaf stripe form of esca induces alteration of photosynthesis and defence reactions in presymptomatic leaves. Funct. Plant Biol. 38 (11), 856-866.

Mennucci, B., Claps, M., Evidente, A., Rosini, C.J., 2007. Absolute configuration of natural cyclohexene oxides by time dependent density functional theory calculation of the optical rotation: the absolute configuration of (-)-sphaeropsidone and (-)-episphaeropsidone revised. Org. Chem. 72, 6680-6691.

Miller, M.W., 1968. The structure of terremutin. Tetrahedron 24, 4839-4851.

Mizuba, S., Lee, K., Jiu, J., 1975. Three antimicrobial metabolites from Aspergillus caespitosus. Can. J. Microbiol. 21, 1781-1787.

Mowbray, S.L., Elfström, L.T., Ahlgren, K.M., Andersson, C.E., Widersten, M., 2006 $\mathrm{X}$-ray structure of potato epoxide hydrolase sheds light on substrate specificity in plant enzymes. Protein Sci. 15, 1628-1637.

Mugnai, L., Graniti, A., Surico, G., 1999. Esca (black measles) and brown woodstreaking: two old and elusive diseases of grapevines. Plant Dis. 83, 404-418.

Murayama, T., Sugiyama, T., Yamashita, K., 1987. Syntheses of natura $(+)$-phomalactone, (+)-acetylphomalactone $(+)$-asperlin and their isomers. Agric. Biol. Chem. 51, 2055-2060.

Nasser, Y., Altier, D.J., Barbour, E., Cigan, A.L., Scelonge, C.J., 2001. Production of 6-methylsalicylic acid by expression of a fungal polyketide synthase activates disease resistance in Tobacco. Plant Cell 13, 1401-1410.

Nagasawa, H., Suzuki, A., Tamura, S., 1978. Isolation and structure of (+)-desoxyepiepoxydon and (+)-epiepoxydon, phytotoxic fungal metabolites. Agric. Biol. Chem. 42 (6), 1303-1304.

Phillips, A., 2002. Botryosphaeria species associated with diseases of grapevines in Portugal. Phytopathol. Mediterr. 41, 3-18.

Rahman, M.M., Sarker, S.D., Byres, M., Gray, A., 2004. New salicylic acid and isoflavone derivatives from Flemingia paniculata. J. Nat. Prod. 67, 402-406.
Ramírez-Suero, M., Bénard-Gellon, M., Chong, J., Laloue, H., Stempien, E., AbouMansour, E., Fontaine, F., Larignon, P., Mazet-Kieffer, F., Farine, S., Bertsch, C. 2014. Extracellular compounds produced by fungi associated with Botryosphaeria dieback induce differential defence gene expression patterns and necrosis in Vitis vinifera cv. Chardonnay cells. Protoplasma. http:// dx.doi.org/10.107/s00709-014-0643-y.

Sasaki, M., Kaneko, Y., Oshita, K., Takamatsuy, H., Asao, A., Yokotsuka, T., 1970. Compounds produced by molds. VII. Isolation of isocoumarin compounds. Agric. Biol. Chem. 34 (9), 1296-1300.

Spagnolo, A., Larignon, P., Magnin-Robert, M., Hovasse, A., Cilindre, C., Van Dorsselaer, A., Clément, C., Schaeffer-Reiss, C., Fontaine, F., 2014a. Flowering as the most highly sensitive period of grapevine (Vitis vinifera L. cv Mourvèdre) to the botryosphaeria dieback agents Neofusicoccum parvum and Diplodia seriata infection. Int. J. Mol. Sci 15 (6), 9644-9669. http://dx.doi.org/10.3390/ ijms15069644.

Spagnolo, A., Magnin-Robert, M., Alayi, T.D., Cilindre, C., Schaeffer-Reiss, C., Van Dorsselaer, A., Clément, C., Larignon, P., Ramirez-Suero, M., Chong, J., Bertsch, C., Abou-Mansour, E., Fontaine, F., 2014b. Differential responses of three grapevine cultivars to Botryosphaeria dieback. Phytopathology 104 (10), 1021-1035 (dx.doi.org/10.1094/PHYTO-01-14-0007-R).

Taylor, A., Hardy, G.E., St, J., Wood, P., Burgess, T., 2005. Identification and pathogenicity of Botryosphaeria species associated with grapevine decline in Western Australia. Australas. Plant Pathol. 34, 187-195.

Tripathi, B.N., Bhatt, I., Dietz, K.J., 2009. Peroxiredoxins: a less studied component of hydrogen peroxide detoxification in photosynthetic organisms. Protoplasma 235, 3-15.

Tsuda, Y., Nunozawa, T., Nitta, K., Yamamoto, Y., 1980. Stereochemical correlation of di- and trihydroxy- $\beta$-diketone fungal metabolites, (-)-terredionol and terremutin hydrate, with sugar alcohols: the absolute configuration of (-)-terredionol. Chem. Pharm. Bull. 28, 920-925.

Turner, W.B., Aldridge, D.C., 1983. Fungal Metabolites II. Academic Press, London.

Úrbez-Torres, J.R., Leavitt, G.M., Voegel, T.M., Gubler, W.D., 2006. Identification and distribution of Botryosphaeria spp. Associated with grapevine cankers in California. Plant Dis. 90, 1490-1503.

Úrbez-Torres, J.R., 2011. The status of Botryosphaeriaceae species infecting grapevines. Phytopathol. Mediterr. 50, S5-S45.

Van Niekerk, J.M., Crous, P.W., Groenewald, J.Z., Fourie, P.H., Halleen, F., 2004. DNA phylogeny, morphology and pathogenicity of Botryosphaeria species on grapevines. Mycologia 96, 781-798.

Venkatasubbaiah, P., Kohmoto, K., Otani, H., Hamasaki, T., Nakajima, H., Hokama, K., 1987. Two phytotoxins from Stagnospora sacchari causing leaf scorch of sugarcane. Nippon Shokubutsu Byori Gakkaiho 53, 335-344.

Venkatasubbaiah, P., Chilton, W.S., 1992. An epoxydon-derived ester from a Phoma sp. pathogenic to rhubarb. J. Nat. Prod. 55 (5), 639-643.

Venkatasubbaiah, P., Sutton, T.B., Chilton, W.S., 1995. The structure and biological properties of secondary metabolites produced by Peltaster fructicola, a fungus associated with apple sooty blotch disease. Plant Dis. 79, 1157-1160.

Yang, Z.C., Jiang, X.B., Wang, Z.-M., Zhou, W.S., 1997. Total syntheses of (+)-asperlin, $(+)$-acetylphomalactone and (5S,6S,7R,8S)-asperlin based on the kinetic resolution of 2-furylmethanols. J. Chem. Perkin Trans. 1, 317-321.

Zhang, H., Xiong, Y., Zhao, H., Yi, Y., Zhang, C., Yu, C., Xu, C., 2013. An antimicrobial compound from the endophytic fungus Phoma sp. isolated from the medicinal plant Taraxacum mongolicum. J. Taiwan Inst. Chem. E. 44, 177-181.

Zhou, S., Smith, D.R., Stanosz, G.R., 2001. Differentiation of Botryosphaeria species and related anamorphic fungi using Inter Simple or Short Sequence Repeat (ISSR) fingerprinting. Mycol. Res. 5, 919-926.

Xia, X., Qi, J., Wei, F., Jia, A., Yuan, W., Meng, X., Zhang, M., Liu, C., Wang, C., 2011. Isolation and characterization of a new benzofuran from the fungus Alternaria sp. (HS-3) associated with a sea cucumber. Nat. Prod. Commun. 6, 1913-1914. 